\title{
Epicardial Ablation in Brugada Syndrome
}

Rui Providência ${ }^{1,2}$ MD PhD, Pier D Lambiase ${ }^{1,3}$ FRCP PhD

${ }^{1}$ St Bartholomew's Hospital, Barts Heart Centre, Barts Health NHS Trust, London, United Kingdom; ${ }^{2}$ Institute of Health Informatics, University College of London, London, United Kingdom, ${ }^{3}$ Institute of Cardiovascular Science, University College of London, London, United Kingdom; r.providencia@ucl.ac.uk; p.lambiase@ucl.ac.uk

\section{Synopsis (1-paragraph)}

Subsets of patients with Brugada syndrome can present with frequent and recurring ventricular fibrillation episodes. Besides medical management with quinidine, only catheter ablation can help reduce the arrhythmia burden in these patients. This review explores the existing evidence on ablating these individuals' arrhythmic substrate from the epicardium.

Key words: arrhythmia, channelopathies, sudden cardiac death, repolarization abnormalities, depolarization abnormalities, ventricular fibrillation, mapping, substrate, triggers.

\section{Key Points:}

- Catheter ablation in experienced centres should be offered to patients with Brugada syndrome and recurring ventricular fibrillation episodes.

- Obtaining epicardial access and ablating areas of low voltage fractionated potentials in the epicardial anterior RV and RVOT is required in most patients.

- This procedure achieved good results with 75 to $100 \%$ of patients being free from arrhythmia relapse during a 2 to 3 year follow-up.

- Complication rate was low.

- Pericarditis and pericardial effusion were the most frequent adverse events and no fatal events were observed. 


\section{Introduction}

Brugada syndrome is an inherited cardiac channelopathy characterized by a typical ECG signature of coved-type ST-segment elevation in the right precordial leads and ventricular arrhythmias leading to sudden cardiac death, in the absence of unequivocal structural heart disease. $^{1}$

The 2017 North American guidelines recommend that an implantable cardioverter defibrillator (ICD) is offered to patients spontaneous type 1 Brugada ECG with expected meaningful survival of greater than 1 year and cardiac arrest, sustained ventricular arrhythmias or a recent history of syncope presumed due to ventricular arrhythmias (Class of Recommendation I, Level of Evidence B obtained from non-randomized trials). ${ }^{2}$ The 2015 European Society of Cardiology guidelines also recommended an ICD for patients with a diagnosis of Brugada syndrome who a) were survivors of cardiac arrest or b) had documentation of sustained VT (Class of Recommendation I, Level of Evidence C). Consideration should be also be given to patients with spontaneous type 1 ECG and history of syncope (Class of Recommendation Ila, Level of Evidence C), or those developing ventricular fibrillation (VF) during programmed ventricular stimulation (Class of Recommendation IIb, Level of Evidence C). ${ }^{3}$

Small case series some authors have suggested quinidine as an alternative to the ICD in selected patients, ${ }^{4,5}$ or as an option for the prevention of arrhythmic storms. ${ }^{6}$ Accordingly, guidelines suggest its use in patients with Brugada syndrome patients with malignant arrhythmias who either are not candidates for or decline an ICD, and ICD recipients with recurring events. ${ }^{2,3}$

Another treatment alternative for preventing sustained ventricular arrhythmia events is catheter ablation. On the recent Expert Consensus on catheter ablation of ventricular 
arrhythmias it has a class Ila recommendation, level of evidence B from non-randomized trials, for patients experiencing recurrent sustained arrhythmia episodes of ICD therapies. ${ }^{7}$ The recent North American guidelines for the management of ventricular arrhythmias and prevention of sudden cardiac death assign catheter ablation a class I recommendation, level of evidence B from non-randomized trials, to the specific subsets of patients: (a) patients with Brugada syndrome and spontaneous type 1 ECG and symptomatic ventricular arrhythmias who are either not candidates to or decline and ICD, and (b) patients with Brugada syndrome implanted with an ICD and experiencing recurrent ventricular arrhythmia episodes. ${ }^{2}$ In the following paragraphs we will discuss this treatment option and the available evidence in more detail.

\section{Electrophysiological Mechanisms in Brugada Syndrome}

The mechanism of the Brugada pattern ECG is still a focus of much debate being broadly categorised into the "Depolarisation" and "Repolarisation" hypotheses respectively. The former explains the ECG patter on the basis that there is a phasic difference in depolarisation of the right ventricular outflow tract and RV body with the delay between the 2 promoting a voltage gradient between the 2 leading to the coved ST elevation. There is certainly evidence to support this from endocardial mapping studies which have demonstarted marked conduction delays in the RVOT of Brugada patients. ${ }^{8,9}$ The alternative repolarisation hypothesis arises from mechanistic studies in the canine wedge preparation which demonstrates that pharmacologically induced action potential duration differences in the epicardium and endocardium result in a transmural repolarisation gradient. These gradients are exaggerated by the spike \& dome shaped epicardial action potential which is shorter in 
duration than the endocardial action potential. Epicardial mapping studies have demonstrated that this action potential shortening does exist in humans and promotes the transmural gradients that can induce the Brugada pattern ECG. ${ }^{10}$ (can't find this paper) However, in order for these gradients to be maintained and not eliminated by electrotonic coupling, it is recognised that structural abnormalities in the form of fibrosis will enable these gradients to be maintained and indeed recent data from myocardial biopsies in Brugada patients supports this demonstrating the presence of fibrosis and connexin downregulation which will promote cellular electrical uncoupling. ${ }^{11}$ Indeed, these structural changes will promote current-load mismatch delaying endo-epicardial activation and lead to ST elevation on the ECG in its own right without having to invoke epicardial action potential shortening in the mechanism. Epicardial mapping studies have demonstrated fractionated electrograms which support discontinuous conduction, ${ }^{12}$ although Anzelevitch proposes these can be explained by localised phase 2 re-entry also reproducing a fractionated bipolar signal. ${ }^{13}$ The fact that ajmaline promotes more fractionation in the diseased epicardium in Brugada patients strongly supports the depolarisation hypothesis with structural abnormalities with endo-epicardial conduction delay. These controversies could be resolved by epi-endocardial mapping studies studying effects of pacing and ajamline on the conduction-repolarisation charcteristics of the RVOT endo and epicardium. ${ }^{14}$

\section{Trigger ablation using an endocardial approach}

Haïssaguerre and colleagues were the first to map and ablate ventricular fibrillation (VF) triggers in Brugada syndrome patients with good results leading to changes in VF-inducibility status, and prevention of VF relapse. ${ }^{15}$ These 3 Brugada syndrome patients had frequent 
isolated or repetitive premature beats which could be mapped to the endocardium of the right ventricular outflow tract or to the anterior right ventricular Purkinje network. However, the occurrence of these triggers is unpredictable and usually not occurring spontaneously, which makes this approach applicable only to a small subset of patients.

More recent work from the Bordeaux group has shown that the low voltage fractionated potential found in the epicardium could be eliminated in 2 patients through long periods of endocardial ablation ( 22 to 30 minutes of radiofrequency ablation with $30-35 \mathrm{~W}$ ). ${ }^{16}$ In the third case, additional epicardial ablation was required. The same group used the multipolar radiofrequency ablation catheter (nMARQ ${ }^{\circledR}$, Biosense-Webster $(C)$ with $25 \mathrm{~W}$ for a mean of 10 minutes, and achieved isolation of the RV outflow tract, elimination of the type 1 Brugada pattern, disappearance of epicardial potentials, and freedom from ventricular fibrillation relapse at 2 years follow-up in a series of 3 patients. ${ }^{17}$

Talib and colleagues have developed a step-wise endocardial ablation approach for treating patients with drug-refractory VF/ electrical storm. ${ }^{18}$ Through a first step of identification and ablation VF triggers, and performing endocardial mapping and ablation of VF substrates with ventricular electrograms exhibiting abnormal low-voltage and fractionation in a second step, the authors were able to achieve moderate success observing freedom from VF relapse in 14 out of 21 patients during a 5-year follow-up.

\section{Epicardial approach - mapping the epicardial substrate}

A new epicardial mapping technique was developed in the 90 s by Sosa and colleagues, in Brasil. ${ }^{19}$ This group was dealing with the endemic and challenging substrate of Chagasic cardiomyopathy with recurrent ventricular tachycardia despite endocardial ablation. It took 
nearly 20 years, but the introduction of the sub-xifoid approach to enter the pericardial space was one of cornerstone steps to make Brugada syndrome ablation with acceptable efficacy a reality.

Nademanee and colleagues changed the paradigm of catheter ablation for Brugada syndrome after their landmark 2011 publication. ${ }^{20}$ In a series of 9 patients with Brugada syndrome and recurrent ICD therapies for VF the authors identified unique abnormal low voltage, prolonged duration, and fractionated late potentials clustering exclusively in the anterior aspect of the RV outflow tract epicardium. The authors classified this as the substrate for Brugada syndrome ECG changes and arrhythmogenecity and concluded that this was proof that the electrophysiological mechanism in this disease was delayed depolarization. Interestingly, all electrograms in the corresponding endocardial sites were normal. As a proof of this concept, ablation of these sites rendered 7 of these patients non-inducible (VF was inducible in all before ablation) and normalized the type-1 Brugada ECG pattern in 8 . Additionally no recurrent events were observed during a 20-month follow-up and all patients, but one, were free from anti-arrhythmic drugs.

Brugada et al. developed an ablation protocol including drug-challenge with flecainide to unmask the functional substrate of Brugada syndrome. ${ }^{21}$ An increase in the area of low voltage fractionated components after administering the drug was observed for every patient. After ablation drug-challenge was used once again to confirm non-inducibility of type $1 \mathrm{BrS}$ pattern, and hence acute procedural success. In cases where type 1 pattern was still present further mapping and ablation was performed until the type 1 pattern could not be induced. With this approach, the authors acutely eradicated type-1 pattern in all patients, and the ECG remained normal after median follow-up of 5 months. All patients had ventricular arrhythmias inducible prior to ablation, but after elimination of the type-1 pattern this was 
no longer possible despite aggressive ventricular stimulation. During follow-up ICD interrogation showed no arrhythmic events.

Subsequently, this group of authors adopted an ajmaline-based approach and a CARTOalgorithm allowing them to create potential duration maps in a semi-automated way to map the area of Brugada syndrome substrate in 135 patients and confirmed the previously reported preliminary results. ${ }^{22}$

Pappone and colleagues, have studied the association of substrate and VF inducibility in a series of 191 patients. They observed that the extension / area of Brugada syndrome substrate is independently associated with arrhythmia inducibility. The authors identified $4.0 \mathrm{~cm}^{2}$ as the area cut-off associated with VF inducibility, and suggested that assessing the area of substrate (using ajmaline to induce type-1 pattern if not present at baseline) can be used to identify high-risk patients missed by standard clinical criteria. ${ }^{23}$

\section{Clinical Experience}

After a brief search of the literature we identified 9 case series including 5 or more patients receiving epicardial ablation. ${ }^{20-22,24-29}$ All included relatively young populations with mean ages ranging from 37 to 48 years (Table 1). Cohorts were composed mostly, or exclusively, of men, and nearly all patients had had ICDs. Brugada and Pappone ablated more than $50 \%$ of patients without previous ICD therapies or documented spontaneously occurring VF prior to ablation. ${ }^{21,22}$

With regards to ablation protocol, minor differences were observed between the different groups of experts (Table 2). All groups except two ${ }^{27,29}$ routinely tested for VF inducibility at the start of the procedure. Substrate ablation was performed exclusively in all but two case 
series. ${ }^{25,28}$ Drug challenge during the procedure was performed in most cohorts, but drugs utilized for induction of the functional substrate varied: Ajmaline ${ }^{22,27-29}$ and Flecainide, ${ }^{21,25}$, were among the different class Ic anti-arrhythmic drugs used. A class la drug, Procainamide, was used in some of the studies, ${ }^{24,26,28}$ and Chung et al. described the use of instilled warm water for the same purpose..$^{25}$

Most groups mapped the epicardium using $3.5 \mathrm{~mm}$ non-irrigated catheters. Use of the Pentaray was reported by two groups ${ }^{25,29}$, the Decanav was also used in two case series, ${ }^{28,29}$ one group reported use of a circular mapping catheter. ${ }^{28}$ No consensus was observed in the utilized ablation settings power ranging from 30 to 50W. Ablation duration for each lesion was not reported frequently, and varied from 30 s to 120 s. Similarly, duration of radiofrequency varied widely even in the same study, going from slightly over 5 minutes in some cases to beyond 30 minutes in others, which can be explained by the differences in functional substrate area observed in this population. In most studies ablation was performed exclusively in the epicardium, usually in the anterior RV outflow tract area. Nademanee et al. observed that in patients with early repolarization syndrome and Brugada syndrome substrate was also very frequently present (in nearly 90\%) in the RV inferior wall. ${ }^{28} \mathrm{~A}$ minority of patients required additional endocardial ablation (Table 2).

3D mapping was used in all cases, with CARTO 3 being the mostly frequently used. A minority of cases were performed with Ensite NavX. ${ }^{26,27}$ Our group has experience of ablating one patient using the Rhythmia system, ${ }^{30}$ but no further experience has yet been reported. Most groups perform point by point mapping with annotation/tagging of areas of interest. A specific and non-commercially available, algorithm for automatic measurement of potential duration, allowing their marking on CARTO (i.e. a potential duration map) was used by Pappone et al. ${ }^{22}$ Our group has observed that Ripple Mapping can be used to identify and 
delineate the areas of long and low voltage fractionated electrograms in the RVOT epicardium. ${ }^{29}$ Retrospective use of this approach identified important areas which were missed for ablation in a patient who later relapsed. ${ }^{31}$

The acute procedural endpoint for all cases was eliminated of the functional substrate and disappearance of the type-1 Brugada syndrome pattern. Most studies performed a drug challenge at the end to confirm non-inducibility of type 1 pattern after substrate ablation. All studies except one tested for VF inducibility post ablation. ${ }^{29}$

Mid-term ablation results were good with freedom from ventricular arrhythmia relapse (73 to $100 \%$ ) and type-1 Brugada pattern in most patients (64 to $100 \%$ ), and a minority of patients requiring anti-arrhythmic drugs post ablation (0 to 33\%).

\section{Potential caveats of the epicardial approach}

Since its original description by Sosa and colleagues, ${ }^{19}$ the epicardial approach for ablation of arrhythmias has been adopted worldwide in experienced centers. Even though the risk of and severity complications reported in the literature is not negligible, in our cohort of patients, ablated in experienced centres, side effects were minor and non-lifetreating (pericardial complications in a minority of patients) (Table 3).

Interestingly, the most severe side effect occurred due to Ajmaline use to unmask the functional substrate in the RV outflow tract.

\section{Future prospects}


The role of prophylactic ablation is still a matter of discussion. There is currently an ongoing trial for addressing that matter, the "Ablation in Brugada Syndrome for Prevention of VF" (BRAVE). ${ }^{32}$ This trial plans to enrol 200 patients with Brugada syndrome implanted with ICD or with an ICD therapy within the last 5 years, and randomize them to ablation vs. conventional care, with a follow-up of 3 years. The estimated completion date will be July 2021.

The early repolarisation pattern has been associated with idiopathic VF and there is emerging data that the sites of VF drivers correspond to regions of fractionation in the epicardium causing J point elevation through similar mechanism to the Brugada pattern ECG. ${ }^{28}$ In a recent study, Nademanee et al. demonstrated that there are 2 groups of Idiopathic VF substrates linked to the Early Repolarization Syndrome/J-wave syndrome: one with late depolarization abnormality as the underlying mechanism of high-amplitude J-wave elevation that predominantly resides in the RV outflow tract and RV inferolateral epicardium (group 1), and the other with pure ERS devoid of VF substrates but with VF triggers that are associated with Purkinje sites (group 2). Ablation was effective in treating symptomatic patients with Early Repolarization Syndrome/J-wave syndrome with frequent VF episodes. In this study the sites of abnormal fractionated electrograms were eliminated by ablation of the epicardial sites using the same ablation settings as in Brugada substrates described above. Using ECG Imaging they demonstrated that late depolarization areas co-localize with VF drivers.

A Brugada pattern ECG was present in most patients in category 1 (33 patients), who were then classified as group $1 \mathrm{~A}$. The remaining 7 patients in group 1, category $1 \mathrm{~B}$, did not have a Brugada type 1 ECG pattern, and the late depolarization abnormalities were located mostly in the RV inferior wall. Ablation results in this series of patients with early repolarization were 
good, with only 3 of the 33 patients with Brugada ECG receiving ablation presenting with VF relapse, and all of the 5 patients in group 1B and 6 in group 2 receiving ablation remaining free from sustained ventricular arrhythmias.

\section{Summary / Discussion}

- Catheter ablation is useful for reducing the arrhythmia burden in Brugada syndrome patients with recurring episodes of VF.

- Even though the epicardial approach has been associated with severe complications, no fatal event or life-changing complications were observed in our review from the literature which included highly experienced centers.

- A Drug-challenge with class Ic agents is frequently required for mapping the full-extent of the target area.

- Controversy still exists regarding the procedural endpoint of catheter ablation of Brugada syndrome, but complete eradication and ablation of the functional substrate should be achieved. Ideally this should lead to the disappearance of the type 1-ECG pattern.

- Debate still exists regarding eradication of the type-1 Brugada pattern and achieving VF non-inducibility at the end of the procedure and their meaning. However, our literature search showed that patients where these acute endpoints were achieved can still experience VF relapse during follow-up. ${ }^{28}$

- It is thought that ablation may eliminate the typical type-1 Brugada ECG and obliterate the RV outflow tract transmural gradient by 2 mechanisms: i) Removal of the epicardial layer of shortened action potential cells or ii) Creation of a transmural lesion 
to obliterate the entire segment of abnormal tissue. In theory the latter would be expected to promote depolarisation delay between the RV body and RV outflow tract and exaggerate the Brugada ECG unless a significant area of delay is neutralised (or simply eliminating the endo-epicardial site of current-load mismatch to prevent ST elevation). 
Figure 1 - example of EGM with typical potentials

Figure 2-example of Ripple mapping 


\section{References}

1. Brugada P, Brugada J. Right bundle branch block, persistent ST segment elevation and sudden cardiac death: a distinct clinical and electrocardiographic syndrome. A multicenter report. J Am Coll Cardiol. 1992;20:1391-6.

2. 2. Al-Khatib SM, Stevenson WG, Ackerman MJ, Bryant WJ, Callans DJ, Curtis AB, Deal BJ, Dickfeld T, Field ME, Fonarow GC, Gillis AM, Granger CB, Hammill SC, Hlatky MA, Joglar JA, Kay GN, Matlock DD, Myerburg RJ, Page RL. 2017 AHA/ACC/HRS Guideline for Management of Patients With Ventricular Arrhythmias and the Prevention of Sudden Cardiac Death. Circulation. 2018;138:e272-e391.

3. Priori SG, Blomström-Lundqvist C, Mazzanti A, Blom N, Borggrefe $M$, Camm J, Elliott PM, Fitzsimons D, Hatala R, Hindricks G, Kirchhof $P$, Kjeldsen K, Kuck KH, Hernandez-Madrid A, Nikolaou N, Norekvål TM, Spaulding C, Van Veldhuisen DJ; Task Force for the Management of Patients with Ventricular Arrhythmias and the Prevention of Sudden Cardiac Death of the European Society of Cardiology (ESC). 2015 ESC Guidelines for the management of patients with ventricular arrhythmias and the prevention of sudden cardiac death: The Task Force for the Management of Patients with Ventricular Arrhythmias and the Prevention of Sudden Cardiac Death of the European Society of Cardiology (ESC)Endorsed by: Association for European Paediatric and Congenital Cardiology (AEPC). Europace. 2015;17:1601-87.

4. Belhassen B, Rahkovich M, Michowitz Y, Glick A, Viskin S. Management of Brugada syndrome: thirty-three-year experience using electrophysiologically guided therapy with class $1 \mathrm{~A}$ antiarrhythmic drugs. Circ Arrhythm Electrophysiol. 2015;8:1393-402.

5. Bouzeman A, Traulle S, Messali A, Extramiana F, Denjoy I, Narayanan K, Marijon E, Hermida JS, Leenhardt A. Long-term follow-up of asymptomatic Brugada patients with inducible ventricular fibrillation under hydroquinidine. Europace. 2014 Apr;16(4):572-7.

6. Márquez MF, Bonny A, Hernández-Castillo E, De Sisti A, Gómez-Flores J, Nava S, Hidden-Lucet $F$, Iturralde $P$, Cárdenas $M$, Tonet J. Long-term efficacy of low doses of quinidine on malignant arrhythmias in Brugada syndrome with an implantable cardioverter-defibrillator: a case series and literature review. Heart Rhythm. 2012;9:1995-2000.

7. Cronin EM, Bogun FM, Maury P, Peichl P, Chen M, Namboodiri N, Aguinaga L, Leite LR, AlKhatib SM, Anter E, Berruezo A, Callans DJ, Chung MK, Cuculich P, d'Avila A, Deal BJ, Della Bella P, Deneke T, Dickfeld TM, Hadid C, Haqqani HM, Kay GN, Latchamsetty R, Marchlinski F, Miller JM, Nogami A, Patel AR, Pathak RK, Saenz Morales LC, Santangeli P, Sapp JL Jr, Sarkozy A, Soejima K, Stevenson WG, Tedrow UB, Tzou WS, Varma N, Zeppenfeld K. 2019 HRS/EHRA/APHRS/LAHRS expert consensus statement on catheter ablation of ventricular arrhythmias. Heart Rhythm. 2019 May 10. pii: S1547-5271(19)30210-3.

8. Lambiase PD, Ahmed AK, Ciaccio EJ, Brugada R, Lizotte E, Chaubey S, Ben-Simon R, Chow AW, Lowe MD, McKenna WJ. High-density substrate mapping in Brugada syndrome: combined role of conduction and repolarization heterogeneities in arrhythmogenesis. Circulation. 2009;120:106-17, 1-4.

9. Postema PG, van Dessel PF, de Bakker JM, Dekker LR, Linnenbank AC, Hoogendijk MG, Coronel $\mathrm{R}$, Tijssen JG, Wilde AA, Tan HL. Slow and discontinuous conduction conspire in Brugada syndrome: a right ventricular mapping and stimulation study. Circ Arrhythm Electrophysiol. 2008;1:379-86.

10. Kanda, Lambiase Circ AE 2019

11. Nademanee K, Raju H, de Noronha SV, Papadakis M, Robinson L, Rothery S, Makita N, Kowase S, Boonmee N, Vitayakritsirikul V, Ratanarapee S, Sharma S, van der Wal AC, Christiansen M, Tan HL, Wilde AA, Nogami A, Sheppard MN, Veerakul G, Behr ER. Fibrosis, Connexin-43, and Conduction Abnormalities in the Brugada Syndrome. J Am Coll Cardiol. 2015;66:1976-1986.

12. Zhang J, Sacher F, Hoffmayer K, O'Hara T, Strom M, Cuculich P, Silva J, Cooper D, Faddis M, Hocini $M$, Haïssaguerre $M$, Scheinman M, Rudy Y. Cardiac electrophysiological substrate 
underlying the ECG phenotype and electrogram abnormalities in Brugada syndrome patients. Circulation. 2015;131:1950-9.

13. Antzelevitch C, Patocskai B. Brugada Syndrome: Clinical, Genetic, Molecular, Cellular, and Ionic Aspects. Curr Probl Cardiol. 2016;41:7-57.

14. Sacher F, Jesel L, Jais $P$, Haïssaguerre $M$. Insight into the mechanism of Brugada syndrome: epicardial substrate and modification during ajmaline testing. Heart Rhythm. 2014;11:732-4.

15. Haïssaguerre $M$, Extramiana $F$, Hocini $M$, Cauchemez B, Jaïs $P$, Cabrera JA, Farré J, Farre $G$, Leenhardt A, Sanders P, Scavée C, Hsu LF, Weerasooriya R, Shah DC, Frank R, Maury P, Delay $M$, Garrigue $S$, Clémenty J. Mapping and ablation of ventricular fibrillation associated with long-QT and Brugada syndromes. Circulation. 2003; 108:925-928.

16. Sacher F, Derval N, Denis A, Zemmoura A, Amraoui S, Berte B, Sellal JM, Hooks D, Yamashita $S$, Al-Jefairi N, Cochet $H$, Ploux $S$, Bordachar $P$, Ritter $P$, Jais $P$, Haissaguerre $M$, Hocini $M$. Endocardial Brugada syndrome ablation to eliminate epicardial substrate. Heart Rhythm. 2015;12(Suppl):S135-S136.

17. Hocini M, Denis A, Shah A, Komatsu Y, Sacher F, Derval N, Jais P, Bernus O, Dubois R, Cochet $H$, Haissaguerre $M$. Elimination of Brugada syndrome phenotype by endocardial ablation using novel multipolar RF ablation catheter. Heart Rhythm 2016;13(Suppl):S94.

18. Talib AK, Takagi M, Shimane A, Nakano M, Hayashi T, Okajima K, Kentaro M, Fukada K, Kowase S, Kurosaki K, Nitta J, Nishizaki M, Yui Y, Talib A, Sato N, Kawamura Y, Hasebe N, Aita S, Sai E, Komatsu Y, Kuroki K, Kaneshiro T, Dongzu X, Tajiri K, Igarashi M, Yamasaki H, Murakoshi N, Kumagai K, Sekiguchi Y, Nogami A, Aonuma K. Efficacy of Endocardial Ablation of DrugResistant Ventricular Fibrillation in Brugada Syndrome. Circ Arrhythm Electrophysiol. 2018;11:e005631.

19. Sosa E, Scanavacca M, d'Avila A, Pilleggi F. A new technique to perform epicardial mapping in the electrophysiology laboratory. J Cardiovasc Electrophysiol. 1996;7:531-6.

20. Nademanee K, Veerakul G, Chandanamattha P, Chaothawee L, Ariyachaipanich A, Jirasirirojanakorn K, Likittanasombat K, Bhuripanyo K, Ngarmukos T. Prevention of ventricular fibrillation episodes in Brugada syndrome by catheter ablation over the anterior right ventricular outflow tract epicardium. Circulation. 2011;123:1270-9.

21. Brugada J, Pappone C, Berruezo A, Vicedomini G, Manguso F, Ciconte G, Giannelli L, Santinelli V. Brugada Syndrome Phenotype Elimination by Epicardial Substrate Ablation. Circ Arrhythm Electrophysiol. 2015;8:1373-81.

22. Pappone C, Brugada J, Vicedomini G, Ciconte G, Manguso F, Saviano M, Vitale R, Cuko A, Giannelli L, Calovic Z, Conti M, Pozzi P, Natalizia A, Crisà S, Borrelli V, Brugada R, SarquellaBrugada G, Guazzi M, Frigiola A, Menicanti L, Santinelli V. Electrical Substrate Elimination in 135 Consecutive Patients With Brugada Syndrome. Circ Arrhythm Electrophysiol. 2017; 10:e005053

23. Pappone C, Ciconte G, Manguso F, Vicedomini G, Mecarocci V, Conti M, Giannelli L, Pozzi P, Borrelli V, Menicanti L, Calovic Z, Della Ratta G, Brugada J, Santinelli V. Assessing the Malignant Ventricular Arrhythmic Substrate in Patients With Brugada Syndrome. J Am Coll Cardiol. 2018;71:1631-1646.

24. Zhang

25. Chung FP, Raharjo SB, Lin YJ, Chang SL, Lo LW, Hu YF, Tuan TC, Chao TF, Liao JN, Lin CY, Chang YT, Hung Y, Te A, Yamada S, Tasaka H, Wang CT, Chen SA. A novel method to enhance phenotype, epicardial functional substrates, and ventricular tachyarrhythmias in Brugada syndrome. Heart Rhythm. 2017;14:508-517.

26. Shelke A, Tachil A, Saggu D, Jesuraj ML, Yalagudri S, Narasimhan C. Catheter ablation for electrical storm in Brugada syndrome: Results of substrate based ablation. Indian Heart J. 2018 Mar - Apr;70(2):296-302.

27. Haanschoten DM, Elvan A, Postema PG, Smit JJJ, Adiyaman A, Ter Bekke RMA, Asaad N, Aanhaanen WTJ, Misier ARR, Delnoy PPHM, Crijns HJGM, Wilde AAM. Catheter ablation in 
highly symptomatic Brugada patients: a Dutch case series. Clin Res Cardiol. 2019 Sep 2. doi: 10.1007/s00392-019-01540-9. [Epub ahead of print]

28. Nademanee K, Haissaguerre M, Hocini M, Nogami A, Cheniti G, Duchateau J, Behr ER, Saba M, Bokan R, Lou Q, Amnueypol M, Coronel R, Khongphatthanayothin A, Veerakul G. Mapping and Ablation of Ventricular Fibrillation Associated with Early Repolarization Syndrome. Circulation. 2019;140:1477-1490.

29. Providencia et al. (under review)

30. Providência R, Carmo $P$, Moscoso Costa $F$, Cavaco D, Morgado F, Scanavacca M, Adragão $P$. Brugada syndrome is associated with scar and endocardial involvement: Insights from highdensity mapping with the Rhythmia ${ }^{\mathrm{TM}}$ mapping system. Rev Port Cardiol. 2017;36:773.e1773.e4.

31. Providencia R, Cavaco D, Carmo P, et al. Ripple-mapping for the detection of long duration action potential areas in patients with Brugada syndrome. BioRxiv 2018; https://doi. org/10.1101/263145

32. A Randomized, Multi-center Study of Epicardial Ablation in Brugada Syndrome Patients to Prevent Arrhythmia Recurrence. Ablation in Brugada Syndrome for the Prevention of VF (BRAVE), Available at: https://clinicaltrials.gov/ct2/show/NCT02704416 , Last assessed $1^{\text {st }}$ of November 2019 
Table 1 - Clinical experience - Epicardial approach for ablation of Brugada syndrome - Baselines

\begin{tabular}{|c|c|c|c|c|c|c|c|c|c|}
\hline Study Id & $\begin{array}{c}\mathrm{N}, \\
\% \text { of } \text { men }\end{array}$ & Mean Age & Region/Countries & ICD & $\begin{array}{l}\text { ICD therapies } \\
\text { or } \\
\text { Documented } \\
\text { VF prior to } \\
\text { Ablation }\end{array}$ & $\begin{array}{c}\text { SCN5A } \\
\text { mutation }\end{array}$ & $\begin{array}{c}\text { Spontaneous } \\
\text { Type-1 BrS } \\
\text { ECG }\end{array}$ & $\begin{array}{c}\text { Use of } \\
\text { Quinidine }\end{array}$ & $\begin{array}{l}\text { Other anti- } \\
\text { arrhythmic } \\
\text { agents }\end{array}$ \\
\hline $\begin{array}{c}\text { Nademanee } \\
201120\end{array}$ & $\begin{array}{c}9 \\
100 \%\end{array}$ & 39 & Thailand & $100 \%$ & $100 \%$ & NS & $78 \%$ & $0 \%$ & $\begin{array}{l}\text { Amiodarone } \\
\text { in } 100 \%\end{array}$ \\
\hline$\underset{21}{\text { Brugada }} 2015$ & $\begin{array}{c}14 \\
100 \%\end{array}$ & 37 & Italy & $100 \%$ & $43 \%$ & $29 \%$ & $86 \%$ & NS & NS \\
\hline Zhang $2016^{24}$ & $\begin{array}{c}11 \\
100 \%\end{array}$ & 48 & China, USA & $73 \%$ & $82 \%$ & $40 \%$ & $82 \%$ & NS & NS \\
\hline Chung 201725 & $\begin{array}{c}15 \\
100 \%\end{array}$ & 41 & Taiwan & NA & $100 \%$ & $20 \%$ & $53 \%$ & NS & NS \\
\hline $\begin{array}{l}\text { Pappone } 2017 \\
22\end{array}$ & $\begin{array}{c}135 \\
78.5 \%\end{array}$ & $39-40$ & Italy & $100 \%$ & $47 \%$ & $24 \%$ & $23 \%$ & NS & NS \\
\hline Shelke $2018^{26}$ & $\begin{array}{c}5 \\
80 \%\end{array}$ & 29 & India & $100 \%$ & $100 \%$ & NS & $100 \%$ & $40 \%$ & $\begin{array}{c}\text { Cilostazol in } \\
100 \%\end{array}$ \\
\hline $\begin{array}{l}\text { Haanschoten } \\
2019^{27}\end{array}$ & $\begin{array}{c}6 \\
83 \%\end{array}$ & 43 & Netherlands & $100 \%$ & $100 \%$ & $67 \%$ & $100 \%$ & $83 \%$ & NS \\
\hline $\begin{array}{c}\text { Nademanee } \\
2019^{28}\end{array}$ & $\begin{array}{c}32 \\
100 \%\end{array}$ & 39 & $\begin{array}{l}\text { Thailand, USA, } \\
\text { Japan, France, UK }\end{array}$ & $100 \%$ & $92 \%$ & $19 \%$ & $64 \%$ & $27 \%$ & NS \\
\hline $\begin{array}{c}\text { Providencia } \\
2019^{29}\end{array}$ & $\begin{array}{c}8 \\
75 \%\end{array}$ & 44 & $\begin{array}{l}\text { Brazil, France, } \\
\text { Portugal, UK }\end{array}$ & $88 \%$ & $75 \%$ & NS & $75 \%$ & $50 \%$ & No \\
\hline
\end{tabular}


Table 2 - Clinical experience - Epicardial approach for ablation of Brugada syndrome - Procedural data

\begin{tabular}{|c|c|c|c|c|c|c|c|c|}
\hline Study Id & $\begin{array}{l}\text { Ablation of } \\
\text { Triggers / } \\
\text { Substrate }\end{array}$ & Ablation Site Epic. & $\begin{array}{l}\text { Ablation Site } \\
\text { Endo. }\end{array}$ & $\begin{array}{c}\text { Drug Challenge } \\
\text { During } \\
\text { Procedure }\end{array}$ & $\begin{array}{c}\text { Power Settings (W) and } \\
\text { Ablation Catheter }\end{array}$ & $\begin{array}{l}\text { Time per } \\
\text { ablation } \\
\text { lesion (s) }\end{array}$ & $\begin{array}{l}\text { Ablation } \\
\text { time } \\
\text { (min) }\end{array}$ & Mapping System \\
\hline $\begin{array}{c}\text { Nademanee } \\
201120\end{array}$ & Substrate & $\begin{array}{l}\text { Anterior RVOT (+++) } \\
\text { RV }\end{array}$ & $\begin{array}{l}\text { None } \\
\text { (all electrograms } \\
\text { were normal in the } \\
\text { Endocardium) }\end{array}$ & NS & $\begin{array}{c}30-50 \mathrm{~W} \\
\text { NaviStar-ThermoCool } \\
\text { 3.5-mm-tip NaviStar-ThermoCool, } \\
\text { Biosense Webster @ }\end{array}$ & NS & 6 to 32 & $\begin{array}{c}\text { CARTO XP } \\
\text { EP Navigation System, } \\
\text { Biosense Webster }{ }^{\circ}\end{array}$ \\
\hline $\begin{array}{c}\text { Brugada } \\
2015^{21}\end{array}$ & Substrate & $\begin{array}{l}\text { Anterior RV free wall } \\
\text { Anterior } \\
\text { RVOT }\end{array}$ & None & Flecainide & $\begin{array}{c}\text { Max 40W } \\
\text { NaviStar-ThermoCool } \\
\text { 3.5-mm-tip NaviStar-ThermoCool, } \\
\text { Biosense Webster } @\end{array}$ & 30 to $60 \mathrm{~s}$ & 11 to 35 & $\begin{array}{c}\text { CARTO 3, Biosense } \\
\text { Webster } @\end{array}$ \\
\hline $\begin{array}{c}\text { Zhang } 2016 \\
24\end{array}$ & Substrate & Anterior RVOT & $9 \%$ & $\begin{array}{l}\text { Propafenone } \\
\text { Procainamide }\end{array}$ & $\begin{array}{c}\text { Up to } 50 \mathrm{~W} \\
\text { 3.5-mm-tip NaviStar-ThermoCool, } \\
\text { Biosense Webster } \subset\end{array}$ & NS & NS & $\begin{array}{c}\text { CARTO 3, Biosense } \\
\text { Webster } \subset\end{array}$ \\
\hline$\underset{25}{\text { Chung } 2017}$ & $\begin{array}{l}\text { Substrate + } \\
\text { Triggers }\end{array}$ & RVOT & $\begin{array}{l}\text { Triggers: } \\
\text { 13\% LV papillary } \\
\text { muscle } \\
\\
20 \% \text { RVOT }\end{array}$ & $\begin{array}{c}\text { Flecainide } \\
\text { Warm Water }\end{array}$ & $\begin{array}{c}\text { Max of } 40 \mathrm{~W} \text { in the endocardium and } \\
30 \mathrm{~W} \text { in the epicardium } \\
\text { NaviStar- } \\
\text { 3.5-mm-tip NaviStar-ThermoCool or } \\
\text { Pentaray, Biosense Webster @ }\end{array}$ & $120 \mathrm{~s}$ & $\begin{array}{c}\text { Mean } \\
27.5\end{array}$ & $\begin{array}{c}\text { CARTO } 3 \text {, Biosense } \\
\text { Webster } ₫\end{array}$ \\
\hline $\begin{array}{c}\text { Shelke } 2018 \\
26\end{array}$ & Substrate & $\begin{array}{l}\text { Anterior RVOT } \\
\quad 80 \% \\
\text { (20\% epicardial } \\
\text { ablation only) }\end{array}$ & $\begin{array}{l}\text { Ablation in } 80 \%: \\
60 \% \text { ant. wall, } 20 \% \\
\text { post. wall, } 20 \% \\
\text { septum } \\
\text { (20\% endocardial } \\
\text { ablation only) }\end{array}$ & $\begin{array}{l}\text { Procainamide in } \\
60 \%\end{array}$ & $\begin{array}{c}\text { Epic: } 30 \mathrm{~W}, 43^{\prime} \mathrm{C} \text { at } 2 \mathrm{ml} / \mathrm{min} \\
\text { Endo: } 30 \mathrm{~W}, 43^{\prime} \mathrm{C} \text { at } 30 \mathrm{ml} / \mathrm{min} \\
\text { Thermocool Celsius, } \\
\text { Biosense Webster } \odot \\
\text { Therapy Cool Path, St.JudeMedical } \odot\end{array}$ & NS & NS & $\begin{array}{l}\text { Ensite Navx mapping } \\
\text { system, Abbott } \subset \\
\text { CARTO } 3 \text { system, } \\
\text { Biosense Webster } @\end{array}$ \\
\hline $\begin{array}{c}\text { Haanschoten } \\
2019^{27}\end{array}$ & Substrate & Anterior RVOT & $\begin{array}{c}17 \% \text { requiring } \\
\text { posteroseptal RVOT } \\
\text { ablation }\end{array}$ & Ajmaline & $\begin{array}{c}\text { NS } \\
\text { NaviStar, ThermoCool or Smart } \\
\text { Touch, Biosense Webster } \subset \\
\text { or Tacticath, Abbott @ }\end{array}$ & NS & NS & $\begin{array}{l}\text { Ensite Navx mapping } \\
\text { system, Abbott } @ \\
\text { CARTO } 3 \text { system, } \\
\text { Biosense Webster } @\end{array}$ \\
\hline $\begin{array}{c}\text { Nademanee } \\
2019^{28}\end{array}$ & $\begin{array}{l}\text { Substrate + } \\
\text { Triggers }\end{array}$ & $\begin{array}{l}\text { Anterior RVOT/RV } \\
\qquad 100 \% \\
\text { Inferior RV } 85 \% \\
\text { Post-Lat LV 3\% }\end{array}$ & $\begin{array}{c}\text { Triggers: } \\
\text { LV-Purkinge system } \\
6 \% \\
\text { LV-posterior wall } \\
3 \%\end{array}$ & $\begin{array}{l}\text { UK, France \& } \\
\text { Tailand: Ajmaline } \\
\text { US \& Japan: } \\
\text { Pilsicainide \& } \\
\text { Procainamide }\end{array}$ & $\begin{array}{c}20-50 \mathrm{~W} \\
\geq 5 \mathrm{~g} \\
\text { Thermocool Celsius, Thermocool } \\
\text { SmartTouch, Lasso, Decanav, } \\
\text { Biosense Webster @ }\end{array}$ & NS & 12 to 45 & $\begin{array}{c}\text { CARTO 3, Biosense } \\
\text { Webster } \subset\end{array}$ \\
\hline
\end{tabular}




\section{Providencia}

$2019^{29}$
30-40W

Anterior RVOT

13\% RVOT

Ajmaline in 50\%

$$
\text { Decanav }
$$

Biosense $W$ 
Table 3 - Clinical experience - Epicardial approach for ablation of Brugada syndrome - Outcomes

\begin{tabular}{|c|c|c|c|c|c|c|c|c|}
\hline Study Id & $\begin{array}{c}\text { VF } \\
\text { inducibility } \\
\text { pre-ablation }\end{array}$ & $\begin{array}{l}\text { VF inducibility } \\
\text { post-ablation }\end{array}$ & $\begin{array}{l}\text { Drug challenge } \\
\text { post-ablation }\end{array}$ & $\begin{array}{l}\text { Mean Follow- } \\
\text { up Duration } \\
\text { (months) }\end{array}$ & $\begin{array}{c}\text { Freedom from } \\
\text { type-1 } \\
\text { Brugada } \\
\text { pattern } \\
\text { relapse }\end{array}$ & $\begin{array}{l}\text { Freedom from } \\
\text { VT/VF relapse }\end{array}$ & $\begin{array}{l}\text { Need of } \\
\text { AADs after } \\
\text { Ablation }\end{array}$ & Complications \\
\hline $\begin{array}{c}\text { Nademanee } \\
2011^{20}\end{array}$ & $100 \%$ & $22 \%$ & None & 20 & $89 \%$ & $100 \%$ & $11 \%$ & $\begin{array}{l}\text { Mild pericarditis } \\
\qquad(n=2)\end{array}$ \\
\hline $\begin{array}{c}\text { Brugada } \\
21\end{array}$ & $100 \%$ & $0 \%$ & Flecainide & 10 & $100 \%$ & $100 \%$ & NS & $\begin{array}{l}\text { Pericarditis } \\
\quad(n=1)\end{array}$ \\
\hline Zhang $2016{ }^{24}$ & $\begin{array}{l}100 \% \\
(n=9)\end{array}$ & $0 \%$ & $\begin{array}{l}\text { Propafenone } \\
\qquad(n=9)\end{array}$ & 25 & $100 \%$ & $73 \% *$ & $0 \%$ & $\begin{array}{l}\text { Pericarditis } \\
\qquad(n=2)\end{array}$ \\
\hline Chung 201725 & $\begin{array}{l}100 \% \\
(n=11)\end{array}$ & $0 \%$ & $\begin{array}{l}\text { Warm water } \\
\text { instillation }\end{array}$ & $3-6$ & $\begin{array}{l}63.6 \% \\
(n=11)\end{array}$ & $93 \%$ & $0 \%$ & None \\
\hline $\begin{array}{l}\text { Pappone } 2017 \\
22\end{array}$ & $100 \%$ & $0 \%$ & Ajmaline & 10 & $98.5 \%$ & $99.3 \%$ & $0 \%$ & $\begin{array}{l}\text { Pericardial effusion } \\
\qquad(n=5)\end{array}$ \\
\hline Shelke $2018^{26}$ & $40 \%$ & $0 \%$ & NS & 46 & $100 \%$ & $80 \%$ & NS & $\begin{array}{l}\text { Pericarditis } \\
\quad(n=1)\end{array}$ \\
\hline $\begin{array}{l}\text { Haanschoten } \\
2019^{27}\end{array}$ & $\begin{array}{l}\text { Not } \\
\text { performed }\end{array}$ & $\begin{array}{c}0 \% \\
\text { (attempted in } \\
4 \text { ) }\end{array}$ & Ajmaline & 43 & $67 \%$ & $83 \%$ & $33 \%$ & $\begin{array}{l}\text { Electrical storm } \\
\text { and } \\
\text { haemodynamic } \\
\text { deterioration after } \\
\text { ajmaline } \\
(n=1)\end{array}$ \\
\hline $\begin{array}{c}\text { Nademanee } \\
201928\end{array}$ & $73 \%$ & $15 \%$ & NS & 27 & $3 \%$ & $91 \%$ & $0 \%$ & $\begin{array}{l}\text { Haemopericardium } \\
\qquad(n=1)\end{array}$ \\
\hline $\begin{array}{l}\text { Providencia } \\
2019^{29}\end{array}$ & $\begin{array}{c}\text { Not } \\
\text { performed }\end{array}$ & Not performed & $\begin{array}{c}\text { Ajmaline in } \\
50 \%\end{array}$ & 22 & $100 \% ? ?$ & $87.5 \%$ & $0 \%$ & $\begin{array}{l}\text { Haemopericardium } \\
\qquad(n=1)\end{array}$ \\
\hline
\end{tabular}

* one patient refused an ICD and died suddenly 1 year after ablation. 